Article

\title{
Investigating Stakeholders' Views on Technology Integration: The Role of Educational Leadership for Sustainable Inclusive Education
}

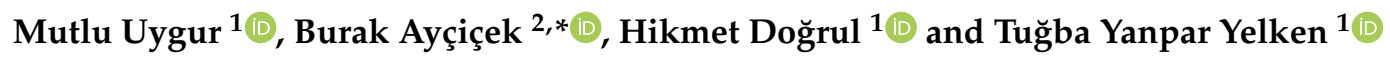 \\ 1 Faculty of Education, Mersin University, Mersin 33110, Turkey; mutluygur@gmail.com (M.U.); \\ hikmet_dogrul@hotmail.com (H.D.); tyanpar@mersin.edu.tr (T.Y.Y.) \\ 2 Department of Child Care and Youth Services, Tokat Gaziosmanpaşa University, Tokat 60250, Turkey \\ * Correspondence: burak.aycicek@gop.edu.tr
}

Received: 22 October 2020; Accepted: 3 December 2020; Published: 11 December 2020

\begin{abstract}
This study aims to determine the views of teachers, school administrative staff having educational leadership roles, and faculty members on integration of technology and the role of educational leadership for sustainable inclusive education. The study group included 38 teachers working in Mersin province, Turkey, 11 school administrative staff, and 11 faculty members working at the Education Faculty. This study was structured employing a "basic interpretive qualitative study model". In the study, a semi-structured interview form consisting of open-ended questions was used as a data collection tool. According to the findings, the faculty members do not consider that inclusive education practices reach an adequate level of sustainability. Therefore, the participants also suggest adding a sustainable inclusive education course in teacher education programs. School administrative staff and teachers have emphasized that technological infrastructures of schools are inadequate for sustainable inclusive education practices. A majority of teachers have used technology in sustainable inclusive education practices. Overall, the participants believe that the integration of technology into sustainable inclusive education has positive effects on students such as ensuring permanent, quick, and easy learning. This study proves that different stakeholders that have a key role in providing sustainable inclusive education handle this issue from different perspectives and they have both positive and negative opinions on the sustainable inclusive education practices.
\end{abstract}

Keywords: sustainable inclusive education; educational leadership; integration of technology; lifelong learning

\section{Introduction}

The educational needs are changing in the 21st century; the concepts of lifelong, inclusive, equal, and fair education form the basis of education and thereby, teachers should respond to the needs of children with different characteristics in their educational processes. It is emphasized that each education system needs to comply with the principles of "non-discrimination, accessibility, flexibility, accommodation to specific needs, alternative approaches to learning and teaching, equality of standards, participation, support for meeting disability-related needs, and preparation for the labour market" [1]. Therefore, a fair-minded understanding of education, where equal opportunities are created for all students, forms the basis of the concept of inclusive education. Inclusive education is an educational approach towards the applications of qualified education and training processes, which are implemented in order to ensure that each student has equal rights in education by creating equal opportunities abiding by plans and objectives. Inclusive education involves a broad range of strategies, activities, and processes for the provision of education as the universal right of everyone if it is of good 
quality and relevant to objectives [2]. The target in inclusive education is to minimize discrimination [3]. In inclusive education, all students, regardless of their differences, are a member of the school community [4]. UNESCO [5] emphasizes that all children and even those in the disadvantaged group should have access to compulsory and quality basic education as part of education for all educational processes. Inclusive education aims to satisfy the needs of each student in order to eliminate obstacles that may arise from individual differences in the educational process [6]. Equal and inclusive education is one of the most essential tools for a fairer community order [7]. Schools in the education system can neutralize the differences by creating a school culture that involves everyone with the warmth and welcoming culture within the school [8]. Situations such as gender, disability status, ethnicity, poverty, or migration in inclusive education are considered as the versatility of inclusive education. According to Ira and Gör [9], the inclusive education process should be guided to provide an ideal education for disadvantaged and migrant children, macro education policies must be developed in this regard for children in the disadvantaged groups, and adequate resources must also be arranged.

The concept of inclusive education is considered as a sustainable process within the scope of sustainable development goals. In the United Nations Sustainable Development Summit held in 2015, global goals were discussed and Sustainable Development Goals expected to be achieved by 2030 were specified [10]. At this summit, 17 themes related to sustainable development were determined. One of these themes is "quality education". Under this theme, the emphasis was made on "providing an inclusive and quality education for everyone and supporting lifelong learning". Similarly, Medina-García, Doña-Toledo, and Higueras-Rodríguez [11] have stated that there is a direct relationship between the process of educational inclusion and the general approach from the Sustainable Development Goals in order to achieve a sustainable future for all. On the other hand, Booth [12] emphasized that sustainability was at the core and made great a contribution to establishing inclusive school structures, procedures, and activities. In this sense, the concept of sustainable inclusive education emerges as one of the components of sustainable development. Sustainability is a broad concept that encompasses economic, social, and environmental goals. Environmental sustainability includes the issues surrounding transport, energy, water, or biodiversity. Economic sustainability refers to the ability of an economy to support a defined level of economic production indefinitely [13]. On the other hand, social sustainability includes the issues as health and safety, ethics, inclusive community, respect, partnerships as well as the ability to work in teams, etc. [14]. In achieving social sustainability, the level of education has a great potential for successful labor market integration [15].

Creating appropriate conditions to ensure that the educational process covers all children and their physical needs and so forth in the process is a prerequisite of sustainable inclusive education for schools to put through such a comprehensive school culture. Studies on sustainable inclusive education consider recognition and appreciation of diversity in educational settings as an approach that concerns attitudes and perceptions throughout the society beyond a set of strategies [5]. As can be understood, sustainable inclusive education has a significant role in keeping up with the changes of the 21th century.

There are important stakeholders who contribute to providing and ensuring sustainable inclusive education successfully at schools. Multiple stakeholders should be involved in the process for a successful inclusion. For this purpose, students, parents, teachers, educational leaders, and specialists must fully follow the principles and procedures required by inclusion. Therefore, stakeholders must work together to ensure inclusive education [16]. Teachers and school administrative staff have some responsibilities such as organizing and guiding the education process as well as guiding students in sustainable inclusive education [17]. In this context, creating opportunities for all students to benefit from the educational process and to develop their potentials is so important [18-20]. School administrators are one of the key factors in the sustainable inclusive education process. The school administrator is the person responsible for all kinds of organizations of the school to achieve education goals at the desired level by means of an efficient and effective organization of teams, tasks, and processes [21]. They are responsible for meeting the needs of the society in a broad sense, and the 
individual in particular, increasing the level of school outputs and the readiness of students [22]. On the other hand, teachers are one of the stakeholders in providing sustainable inclusive education. They need to have training and specific knowledge on the issues handled within sustainability. In addition, the training that will be given to the teachers on the questions of sustainability is an indispensable part of this process [23].

Today, individuals who are critical, problem solvers, knowledgeable about world culture, and that adhere to multiculturalism are needed due to rapid and radical socioeconomic changes, globalization, and the impact of advanced technologies on every aspect of life. These new demands have made the duties of the school administrators more comprehensive and multicomponent [24]. School administrators are also expected to use their educational leadership role effectively in the process of managing the capacities of teachers, students, and parents in terms of achieving the common educational goals [25]. They have to ensure that everyone equally benefits from inclusive programs, by highlighting the benefits and the overall approach to social justice they contribute to. Additionally, they have to create opportunities for all students to have maximum access to the program. Hence, they have to collaborate with other people involved in the sustainable inclusive education team at school. According to Stegemann and Jaciw [26], school administrators have to perform activities that get and give support for participants involved in the education process of the community (i.e., teachers, students, and families) and encourage them in this regard. In addition, they must focus on developing firm relationships with their staff to increase teachers' inclusive practices [27]. Wagner and Katsiyannis [28] argue that if the school administrators are well equipped in terms of educational leadership, they will be better prepared for protecting students' rights and for ensuring that students can get sustainable educational benefits. It is understood that educational leaders are expected to have an understanding of their responsibilities and the roles related to the inclusive education, which provides a successful inclusion [29]. In addition, educational leaders should have positive attitudes and perceptions towards inclusive education [16]. As a result, it is seen that school administrators are at the core of ensuring sustainable inclusive education as educational leaders.

Wong et al. [30] have stated that the educational and information communication technologies play a significant role in creating an effective and adaptable learning environment, especially in the teaching-learning processes carried out for students with special educational needs in sustainable inclusive classrooms. Learners can get more opportunities to understand the learning process via information and communications and media technologies (ICMT) enhanced learning environments than the learning process in face-to-face classroom settings [31]. Technology has a great potential for students in terms of providing access for all learning. Especially, an assistive technology (AT) is a broad concept that covers virtually all things that may be used to meet the needs of those with lack of certain abilities [32]. In this regard, various studies emphasizing the importance of using technology in special education within sustainable inclusive classrooms have been conducted in the literature [33-38]. Therefore, it is required for teachers to have a suitable school environment and school climate in schools to use technology effectively in sustainable inclusive education. In this sense, school administrative staff who have educational leadership roles have important duties and responsibilities in order for teachers to use technology in sustainable inclusive education activities in their schools.

Today, the use of information communication technologies has been insufficient in sustainable inclusive and special needs education. At this point, Starcic [39] has highlighted that competencies of teachers related to using technology and sustainable inclusive education are poor. According to Starcis [40], it is important for prospective teachers to understand that educational technology helps students with special educational needs and teaching process in sustainable inclusive classrooms. In this context, the school administrator is expected to take educational leadership role and provide technological leadership [22]. At this point, educational leaders are expected to ensure the sustainability of inclusive education activities in schools, to take all kinds of precautions and measures, and to provide a technology infrastructure and environment in accordance with today's student expectations and needs. In this sense, the integration of technology into education and the approaches of school 
administrators having an educational role towards both sustainable inclusive education and the use of technology for sustainable inclusive education are essential.

Based on the information in the literature, it is seen that technology has started to be used intensely in today's educational environments. It is now almost impossible to evaluate education independently from technology [41]. Education has been one of the areas affected by the pandemic process that emerged in 2020. In the context of sustainable inclusive education, efforts have been made to make arrangements to ensure that every child can benefit from access to education equally and fairly. In the context that emerged as a result of pandemic process, it is seen that some environments and arrangements such as live lessons organized within distance education activities, technology classes in schools for students who do not have internet access at home, etc., are vital for the sustainability of inclusive education.

Faculty members, teachers, and school administrative staff are seen as important stakeholders in the preparation of programs, organization, and implementation of sustainable inclusive education activities [16]. Therefore, this study tried to determine the approaches, opinions, and suggestions of the stakeholders for the role of the educational leaders responsible for sustainable inclusive education, the integration of technology into sustainable inclusive education, and the technology-based organization of sustainable inclusive education activities in order to realize sustainable inclusive education activities and to reach a judgment. Considering the literature in inclusive education, most studies are conducted for the education of disabled students [42-45] and the diversities caused by language, religion, ethnicity, and migration, which are considered as the versatility of inclusive education [3,8,18,46-52] in recent years. However, there are almost no studies analyzing and interpreting the opinions of teachers, school administrative staff, and faculty members on the integration of technology and the role of educational leaders in sustainable inclusive education through a qualitative research design.

Addressing this research gap makes up the significance of this study. Therefore, this study is considered important in determining the views of participants, having duties and responsibilities in sustainable inclusive education activities, on the use and integration of technology into sustainable inclusive education and the role of educational leaders; and to develop suggestions for the integration of technology into sustainable inclusive education programs accordingly.

This study aims to determine the views of teachers, school administrators and faculty members related to the integration of technology into sustainable inclusive education and the role of educational leaders to contribute to the field by developing suggestions regarding sustainable inclusive education programs. The main problem statement of the study was determined as "what are the views of teachers, school administrative staff, and faculty members on the integration of technology into sustainable inclusive education and the role of educational leadership?"

In this respect, answers to the following sub-problems were sought in the study.

1. What are the views of faculty members on sustainable inclusive education, integration of technology into sustainable inclusive education, and the role of educational leadership?

2. What are the views of school administrative staff having educational leadership roles on sustainable inclusive education, integration of technology into sustainable inclusive education, and the role of educational leadership?

3. What are the views and suggestions of teachers on sustainable inclusive education, integration of technology into sustainable inclusive education, and the role of educational leadership?

\section{Materials and Methods}

\subsection{Research Model}

The basic interpretive qualitative study model was employed in this study, which is the most common form of qualitative research used in the field of education [53]. In a basic interpretive qualitative study, the researcher is interested in how people make sense of and interpret their experiences [54]. 
In this sense, the term "basic" is used for distinguishing this study from other specific forms of qualitative studies such as phenomenology, ethnography, and grounded theory, while also bearing an additional meaning that distinguishes this study from "applied" research [55]. Researchers conducting basic qualitative studies are interested in how people interpret their lives, how they build their world, and what meanings they add to their experiences. Basic qualitative studies reveal detailed accounts of a phenomenon, interpretations of the phenomenon (relationships between the conceptual categories and previous research), and new insights [53]. Therefore, it was decided to use a basic interpretive qualitative research design in this study in order to obtain in-depth and detailed views and comments about sustainable inclusive education, integration of technology into sustainable inclusive education, and the role of educational leadership. In addition, such a study is needed to guide applied research. The basic qualitative studies can guide the applied research in a meaningful way.

\subsection{Study Group}

Of purposeful sampling methods, the criterion sampling technique was employed in the study to determine the study participants. Purposeful sampling consists of the selection of a small number of subjects from a particular population or culture with regards to specific criteria determined by the nature of the research question [56]. The criterion sampling technique involves the inclusion of individuals who serve the purpose of a particular study as criteria [57]. In this study, active involvement in the process of sustainable inclusive education practices was determined as the convenience sampling criteria. The study group of the study consisted of 38 teachers working in Mersin province, 11 school administrative staff, and 11 faculty members working at the Education Faculty. Besides information about independent variables such as gender, age, title, professional experience, and department in the personal information form, "knowledge of sustainable inclusive education, having education for sustainable inclusive education, and providing training for sustainable inclusive education" were also questioned. The information about the study participants is given in Table 1.

Table 1. Personal information regarding participants.

\begin{tabular}{|c|c|c|c|c|c|c|c|}
\hline \multirow[t]{2}{*}{ Variables } & & \multicolumn{2}{|c|}{$\begin{array}{c}\text { Faculty } \\
\text { Members }\end{array}$} & \multicolumn{2}{|c|}{$\begin{array}{c}\text { School } \\
\text { Administrative } \\
\text { Staff }\end{array}$} & \multicolumn{2}{|c|}{ Teachers } \\
\hline & & f & $\%$ & f & $\%$ & f & $\%$ \\
\hline \multirow{2}{*}{ Gender } & Female & 7 & 63.6 & 3 & 27.3 & 28 & 73.7 \\
\hline & Male & 4 & 36.4 & 8 & 72.7 & 10 & 26.3 \\
\hline \multirow{4}{*}{ Age } & $21-30$ & - & & 2 & 18.2 & 2 & 5.3 \\
\hline & $31-40$ & 5 & 45.5 & 5 & 45.5 & 12 & 31.6 \\
\hline & $41-50$ & 6 & 54.5 & 3 & 27.3 & 18 & 47.4 \\
\hline & 51 and above & - & & 1 & 9.1 & 6 & 15.8 \\
\hline \multirow{3}{*}{ Title } & Dr. Faculty Member & 4 & 36.4 & - & - & - & - \\
\hline & Associate Prof. Dr. & 6 & 54.5 & - & - & - & - \\
\hline & Prof. Dr. & 1 & 9.1 & - & - & - & - \\
\hline \multirow{3}{*}{ Professional Experience } & $1-10$ years & 2 & 18.2 & 7 & 63.6 & 4 & 10.5 \\
\hline & $11-20$ years & 5 & 45.5 & 3 & 27.3 & 20 & 52.6 \\
\hline & 21 years and above & 4 & 36.4 & 1 & 0.1 & 14 & 36.9 \\
\hline
\end{tabular}


Table 1. Cont.

\begin{tabular}{|c|c|c|c|c|c|c|c|}
\hline \multirow[t]{2}{*}{ Variables } & & \multicolumn{2}{|c|}{$\begin{array}{c}\text { Faculty } \\
\text { Members }\end{array}$} & \multicolumn{2}{|c|}{$\begin{array}{c}\text { School } \\
\text { Administrative } \\
\text { Staff }\end{array}$} & \multicolumn{2}{|c|}{ Teachers } \\
\hline & & $\mathbf{f}$ & $\%$ & f & $\%$ & f & $\%$ \\
\hline \multirow{7}{*}{ Department } & $\begin{array}{l}\text { Curriculum and } \\
\text { Instruction }\end{array}$ & 6 & 54.5 & - & - & - & - \\
\hline & $\begin{array}{l}\text { Measurement and } \\
\text { Evaluation in } \\
\text { Education }\end{array}$ & 1 & 9.1 & - & - & - & - \\
\hline & $\begin{array}{l}\text { School Counseling } \\
\text { and Guidance }\end{array}$ & 2 & 18.2 & - & - & - & - \\
\hline & Computer and & & & & & & \\
\hline & $\begin{array}{l}\text { Instruction } \\
\text { Technology }\end{array}$ & 2 & 18.2 & - & - & - & - \\
\hline & Primary School & - & - & 10 & 9.1 & 6 & 15.8 \\
\hline & Kindergarten & - & - & 1 & 90.9 & 32 & 84.2 \\
\hline Knowledge of Sustainable & Yes & 11 & 100 & 10 & 90.9 & 30 & 78.9 \\
\hline Inclusive Education & No & 0 & 0 & 1 & 9.1 & 8 & 21.1 \\
\hline Having Education for & Yes & 2 & 18.2 & 9 & 81.8 & 31 & 81.6 \\
\hline Sustainable Inclusive Education & No & 9 & 81.8 & 2 & 18.2 & 7 & 18.4 \\
\hline Providing Training for & Yes & 1 & 9.1 & 4 & 36.4 & 22 & 57.9 \\
\hline Sustainable Inclusive Education & No & 10 & 90.9 & 7 & 63.6 & 16 & 42.1 \\
\hline
\end{tabular}

\subsection{Data Collection Process}

Researchers reviewed relevant studies in national and international literature. In line with these studies, the decision was made on which measurement tools to use. The "personal information form and open-ended question forms" used in the study were prepared by researchers for teachers, school administratiors, and academic staff. In each questionnaire form, there were six questions on the views' of teachers, school administrators, and academic staff on some aspects of sustainable inclusive education. While determining the questions to be asked, a detailed literature review was made regarding sustainable inclusive education, and the related studies were examined. In addition, the opinions and suggestions of a specialist in the field of curriculum development were taken. Great attention was paid to prepare the questions in a way to reflect the purpose of the study in the best way. The questions were also checked in terms of suitability, clarity, and comprehensibility.

Before collecting the data, the participants of the study were informed about the context and the purpose of the study. The prepared questionnaire was sent to some of the participants via e-mail due to pandemic process, and they also sent their replies through e-mail. On the other hand, face-to-face interviews were conducted with most of the participants. The data collection process lasted nearly one month. The interviews were conducted one by one and lasted nearly half an hour.

\subsection{Data Collection Tools}

A personal information form was used in this study to collect participants' personal information, and an open-ended question forms were used to determine views of participants about sustainable inclusive education.

\subsubsection{Personal Information Form}

The personal information form prepared by researchers examining the measurement tools used in the literature, included questions about gender, age, school type, education status, title, and work experience of teachers, school administrative staff, and faculty members. The personal information form also included questions intended for obtaining information about the participants' "knowledge of 
sustainable inclusive education, having education about sustainable inclusive education, and providing training for sustainable inclusive education".

\subsubsection{Open-Ended Question Forms}

The data in the study were collected using open-ended question forms. Reja et al. [58] asserts that it provides individuals an opportunity to give natural and honest responses to open-ended questions independent of the researcher, and this allows the researcher to reach the truth. In this context, three forms including six open-ended questions were prepared to determine the views of teachers, school administrative staff, and faculty members. In the first phase, 10 open-ended questions were prepared by the researchers. These questions were then given to two faculty members working at the Department of Curriculum and Instruction and five Ph.D. students studying in the fields of educational sciences for expert opinions. In line with expert opinions, open-ended forms consisting of six different questions were determined for teachers, school administrative staff, and faculty members in the study group.

\subsection{Data Analysis}

Data from open-ended questions were analyzed using the content analysis method. Content analysis is a scientific approach that assists systematic analysis of the data. The main purpose of content analysis is to find the concepts and relationships that facilitate explanation of collected data and to reveal the themes that enable organizing and making the collected information comprehensible [59]. The basic procedure in content analysis is to aggregate similar data within the framework of specific concepts and themes and to organize and interpret them in a way that the reader can understand [60].

\subsection{Validity and Reliability}

The views of teachers, school administrative staff, and faculty members on sustainable inclusive education and the integration of technology into sustainable inclusive education were independently evaluated by two different experts. Subsequently, two experts determined the common categories and codes by discussing the views they analyzed according to different themes. Moreover, the inter-coder compatibility values concerning the codes and categories identified by experts were examined. The Miles-Huberman reliability formula was used to compute the reliability of the study. According to Miles-Huberman's coder reliability formula, the reliability percentage is derived from the "reliability percentage $=$ agreements/(total number of agreements + disagreements $) \times 100$ " formula, and achieving at least $80 \%$ of reliability is expected [61]. The reliability value is reported in percentage ranging between 0 and 1 (e.g., reliability percentage $=80 \%$; reliability value $=0.08$ ). As a result of calculations, the reliability values in all sub-questions of the study were found to be above 0.80 . Thus, the coder reliability was ensured based on coder reliability calculations in this study. The Miles-Huberman reliability values obtained from the content analysis are presented in Tables $2-4$, below.

Table 2. Miles-Huberman reliability values for the content analysis of faculty member views.

\begin{tabular}{ccc}
\hline & Opinion Form Qualitative Data Content & Reliability Values \\
\hline 1 & $\begin{array}{r}\text { Views of faculty members on sustainable inclusive education practices in Turkey } \\
2\end{array}$ & Views of faculty members on sustainable inclusive education in teacher \\
education programs & 0.91 \\
3 & Views of faculty members on methods, techniques, strategies, or educational tools & 0.90 \\
and activities related to sustainable inclusive education & 0.85 \\
4 & Views of faculty members on the use of technology in sustainable \\
inclusive education & 0.94 \\
5 & Views of faculty members on the integration of technology into sustainable & 0.85 \\
6 & inclusive education & 0.87 \\
\hline
\end{tabular}


Table 3. Miles-Huberman reliability values for the content analysis of school administrative staff views.

\begin{tabular}{|c|c|c|}
\hline & Opinion Form Qualitative Data Content & Reliability Values \\
\hline 1 & Views of school administrative staff on the role of sustainable inclusive education & 0.89 \\
\hline 2 & $\begin{array}{c}\text { Views of school administrative staff on the conditions that schools should have in } \\
\text { terms of using technology in sustainable inclusive education }\end{array}$ & 0.90 \\
\hline 3 & $\begin{array}{l}\text { Views of school administrative staff on the suitability of schools for technology use } \\
\text { in sustainable inclusive education and the technological equipment conditions }\end{array}$ & 0.85 \\
\hline 4 & $\begin{array}{l}\text { Views of school administrative staff on the effects of using technology in } \\
\text { sustainable inclusive education }\end{array}$ & 0.91 \\
\hline 5 & $\begin{array}{l}\text { Views of school administrative staff on the support they provide for effective use of } \\
\text { technology in sustainable inclusive education }\end{array}$ & 0.89 \\
\hline 6 & Views of school administrative staff on the role of educational leadership & 0.93 \\
\hline & Opinion Form Qualitative Content Data & Reliability Values \\
\hline 1 & Views of teachers on sustainable inclusive education practices & 0.93 \\
\hline 2 & $\begin{array}{c}\text { Views of teachers on principles, methods, techniques, strategies, and educational } \\
\text { tools in sustainable inclusive education }\end{array}$ & 0.88 \\
\hline 3 & $\begin{array}{c}\text { Views of teaches on the integration of technology into sustainable } \\
\text { inclusive education }\end{array}$ & 0.90 \\
\hline 4 & $\begin{array}{c}\text { Views of teachers on the effects of integrating technology into sustainable } \\
\text { inclusive education }\end{array}$ & 0.91 \\
\hline 5 & $\begin{array}{c}\text { Views of teachers on problems related to the use of technology in sustainable } \\
\text { inclusive education }\end{array}$ & 0.87 \\
\hline 6 & Views of teachers on the role of educational leadership & 0.90 \\
\hline
\end{tabular}

\section{Results}

\subsection{Findings on the First Sub-Problem}

In the first sub-problem of the study, perspectives of faculty members on the adequacy of sustainable inclusive education practices in Turkey, and their reasons are given in Table 5 below.

Table 5. Views of faculty members on the adequacy of sustainable inclusive education practices in Turkey and their reasons.

\begin{tabular}{|c|c|c|c|c|c|c|}
\hline Category & f & $\%$ & Codes & & f & $\%$ \\
\hline \multirow{7}{*}{ Inadequate } & 11 & 100 & Lack of quality in sustainable inclusive education & & 5 & 33.3 \\
\hline & & & $\begin{array}{l}\text { Inefficient use of supports provided by UNICEF, } \\
\text { ministry of national education (MoNE), social support } \\
\text { program (SSP), and development agencies }\end{array}$ & & 3 & 20 \\
\hline & & & $\begin{array}{c}\text { Teacher-related factors (lack of awareness, not taking } \\
\text { responsibility, not receiving pre-service and } \\
\text { in-service training) }\end{array}$ & & 3 & 20 \\
\hline & & & $\begin{array}{l}\text { Failure to achieve standardization in physical } \\
\text { conditions (regions, schools, and classrooms) }\end{array}$ & & 2 & 13.3 \\
\hline & & & $\begin{array}{l}\text { Lack of business schools for sustainable } \\
\text { inclusive education }\end{array}$ & & 1 & 6.7 \\
\hline & & & Lack of supervision & & 1 & 6.7 \\
\hline & & & & Total & 15 & 100 \\
\hline Adequate & - & - & - & & - & - \\
\hline
\end{tabular}


According to Table 5, it was found that faculty members did not consider the sustainable inclusive education practices to be at an adequate level in Turkey $(\mathrm{f}=11 ; 100 \%)$. They stated that this was due to the lack of quality in sustainable inclusive education program ( $\mathrm{f}=5 ; 33.3 \%)$; inefficient use of supports provided by UNICEF, MoNE, SSP, and Development Agencies ( $\mathrm{f}=3 ; 20 \%$ ); and factors related to teachers such as lack of awareness, not taking responsibility, not receiving pre-service and in-service training $(\mathrm{f}=3 ; 20 \%)$.

The findings related to the views, justifications, and suggestions of faculty members on the importance of learning outcomes related to sustainable inclusive education in the teacher education programs are given in Table 6 below.

Table 6. Views, justifications, and suggestions of faculty members on the importance of learning outcomes related to sustainable inclusive education in teacher education program.

\begin{tabular}{|c|c|c|c|c|c|c|c|c|}
\hline Category & Codes-Reasons & & f & $\%$ & Codes-Suggestions & & $\mathbf{f}$ & $\%$ \\
\hline \multirow{5}{*}{ Important } & $\begin{array}{l}\text { Providing equal } \\
\text { opportunities }\end{array}$ & & 7 & 70 & \multirow{3}{*}{$\begin{array}{l}\text { Sustainable inclusive education } \\
\text { courses should be opened } \\
\text { (Preliminary preparation process for } \\
\text { acquiring knowledge and skills, } \\
\text { application, preparation, } \\
\text { communication, concentration, } \\
\text { and awareness training) }\end{array}$} & & \multirow[b]{3}{*}{15} & \multirow[b]{3}{*}{94} \\
\hline & $\begin{array}{c}\text { Meeting } \\
\text { community needs }\end{array}$ & & 2 & 20 & & & & \\
\hline & $\begin{array}{l}\text { Preliminary } \\
\text { preparation } \\
\text { process for } \\
\text { students with } \\
\text { different } \\
\text { characteristics for } \\
\text { the future }\end{array}$ & & 1 & 10 & & & & \\
\hline & & & & & $\begin{array}{c}\text { Professional development systems } \\
\text { should be established }\end{array}$ & & 1 & 6 \\
\hline & & Total & 10 & 100 & & Total & 16 & 100 \\
\hline \multicolumn{2}{|c|}{ Unimportant } & & - & - & - & & - & - \\
\hline
\end{tabular}

According to Table 6, all faculty members considered the learning outcomes related to sustainable inclusive education important in the teacher education programs $(\mathrm{f}=10 ; 100 \%)$. They considered these learning outcomes important since sustainable inclusive education provided awareness on equal opportunity $(\mathrm{f}=7 ; 70 \%)$. Thus, faculty members proposed opening sustainable inclusive education courses in undergraduate programs in education faculties ( $\mathrm{f}=15 ; 94 \%$ ).

Findings related to the perspectives of faculty members regarding the appropriate methods, techniques, strategies, educational tools, and activities that teachers can use while organizing lessons in sustainable inclusive education are given in Table 7 below.

As shown in Table 7, the views of faculty members on the appropriate methods, techniques, strategies, educational tools, and activities that teachers could use when organizing lessons in sustainable inclusive education were analyzed under "organizing classroom climate, out-of-school support, and activity types" categories. In the category of organizing classroom climate, the faculty members $(f=2 ; 50 \%$ ) underlined the importance of creating rich learning environments considering the principle of functionality. In the out-of-school support category, they emphasized the importance of family involvement and family guidebooks $(f=2 ; 50 \%)$. In the activity types category, the faculty member emphasized that student-centered activities $(f=13 ; 100 \%)$ such as group work, cooperative learning, individualized teaching, and drama activities are important and effective activities in sustainable inclusive education. 
Table 7. Views of faculty members on appropriate methods, techniques, strategies, educational tools, and activities that teachers can use while organizing lessons in sustainable inclusive education.

\begin{tabular}{|c|c|c|c|c|}
\hline Category & Codes & & f & $\%$ \\
\hline \multirow{4}{*}{$\begin{array}{c}\text { Organizing } \\
\text { Classroom Climate }\end{array}$} & $\begin{array}{l}\text { Rich learning environments created based on the principle } \\
\text { of functionality }\end{array}$ & & 2 & 50 \\
\hline & Creating a classroom atmosphere that prioritizes empathy & & 1 & 25 \\
\hline & Creating flipped classroom model & & 1 & 25 \\
\hline & & Total & 4 & 100 \\
\hline \multirow{4}{*}{$\begin{array}{l}\text { Out-of-School } \\
\text { Support }\end{array}$} & Family involvement-family guidebooks & & 2 & 50 \\
\hline & Functional psychosocial support program & & 1 & 25 \\
\hline & Support rooms & & 1 & 25 \\
\hline & & Total & 4 & 100 \\
\hline \multirow{10}{*}{ Activity Types } & Group work activities & & 2 & 15 \\
\hline & Cooperative learning activities & & 2 & 15 \\
\hline & Individualized teaching activities & & 2 & 15 \\
\hline & Drama activities & & 2 & 15 \\
\hline & Case study activities & & 1 & 8 \\
\hline & Discussion activities & & 1 & 8 \\
\hline & Game-based activities & & 1 & 8 \\
\hline & Computer-assisted teaching & & 1 & 8 \\
\hline & Interactive-flexible activities & & 1 & 8 \\
\hline & & Total & 13 & 100 \\
\hline
\end{tabular}

Findings related to the views of faculty members regarding the effective use of technology in sustainable inclusive education are given in Table 8 below.

Table 8. The views of faculty members on the effective use of technology in sustainable inclusive education.

\begin{tabular}{|c|c|c|c|c|}
\hline Category & Codes & & f & $\%$ \\
\hline \multirow{7}{*}{ Effective Use } & Interactive technology portals (edmodo, edpuzzle, etc.) & & 6 & 37 \\
\hline & The use of digital story & & 3 & 18 \\
\hline & Mobile technology applications & & 3 & 18 \\
\hline & Computer-assisted materials and applications & & 2 & 13 \\
\hline & Flipped classroom applications & & 1 & 7 \\
\hline & Social media & & 1 & 7 \\
\hline & & Total & 16 & 100 \\
\hline
\end{tabular}

As shown in Table 8, the faculty members were of the opinion that technology can be effectively used in sustainable inclusive education through interactive technology portals $(\mathrm{f}=6 ; 37 \%)$, digital stories $(\mathrm{f}=3 ; 18 \%)$, mobile technology applications $(\mathrm{f}=3 ; 18 \%)$, computer-assisted materials and applications $(\mathrm{f}=2 ; 13 \%)$, flipped classroom applications $(\mathrm{f}=1 ; 7 \%)$, and social media $(\mathrm{f}=1 ; 7 \%)$.

Findings related to the views of faculty members regarding the integration of technology into sustainable inclusive education, and its advantages and disadvantages for teachers and students are presented in Table 9 below.

As seen in Table 9, the views of faculty members on the integration of technology into sustainable inclusive education and its advantages and disadvantages for teachers and students indicated that they considered reducing workload and encouraging active participation $(\mathrm{f}=2 ; 25 \%)$ as primary advantages and the infrastructure inadequacy as a primary disadvantage $(\mathrm{f}=3 ; 37.5 \%)$. Faculty members stated that some advantages of integrating technology into sustainable inclusive education for the students were being more enjoyable, encouraging active participation, increasing retention, and being motivated and innovative $(\mathrm{f}=2 ; 13.3 \%$ ), while cost and infrastructure inadequacy were considered as primary disadvantages $(\mathrm{f}=2 ; 40 \%)$. 
Table 9. Views of faculty members on integration of technology into sustainable inclusive education and its advantages and disadvantages for teachers and students.

\begin{tabular}{|c|c|c|c|c|c|c|c|c|}
\hline Category & Codes (Advantages) & & f & $\%$ & Codes (Disadvantages) & & f & $\%$ \\
\hline \multirow{7}{*}{ Teacher } & \multirow{2}{*}{$\begin{array}{c}\text { Reducing workload } \\
\text { Encouraging active } \\
\text { participation }\end{array}$} & & 2 & 25 & \multirow{2}{*}{$\begin{array}{l}\text { Infrastructure inadequacy } \\
\text { Workload in preparation for } \\
\text { information equipment }\end{array}$} & & 3 & 37.5 \\
\hline & & & 2 & 25 & & & 2 & 25 \\
\hline & Being a facilitator & & 1 & 12.5 & Cost & & 2 & 25 \\
\hline & Being conspicuous & & 1 & 12.5 & Encouraging laziness & & 1 & 12.5 \\
\hline & \multirow{3}{*}{$\begin{array}{l}\text { Being more enjoyable } \\
\text { Enabling social } \\
\text { transformation }\end{array}$} & & 1 & 12.5 & & & & \\
\hline & & & 1 & 12.5 & & & & \\
\hline & & Total & 8 & 100 & & Total & 8 & 100 \\
\hline \multirow{11}{*}{ Student } & \multicolumn{2}{|l|}{ Being more enjoyable } & 2 & 13.3 & Cost & & 2 & 40 \\
\hline & \multicolumn{2}{|l|}{$\begin{array}{l}\text { Encouraging active } \\
\text { participation }\end{array}$} & 2 & 13.3 & Infrastructure inadequacy & & 2 & 40 \\
\hline & \multicolumn{2}{|l|}{ Increasing retention } & 2 & 13.3 & Preventing socialization & & 1 & 20 \\
\hline & \multicolumn{2}{|l|}{ Being motivated } & 2 & 13.3 & & & & \\
\hline & \multicolumn{2}{|l|}{ Being innovative } & 2 & 13.3 & & & & \\
\hline & \multicolumn{2}{|l|}{ Being comprehensible } & 1 & 13.3 & & & & \\
\hline & \multicolumn{2}{|l|}{$\begin{array}{l}\text { Offering equal } \\
\text { opportunity }\end{array}$} & 1 & 6.7 & & & & \\
\hline & \multirow{4}{*}{$\begin{array}{l}\text { Making one feel special } \\
\text { Providing rich stimuli } \\
\text { Being independent of } \\
\text { time and space }\end{array}$} & & 1 & 6.7 & & & & \\
\hline & & & 1 & 6.7 & & & & \\
\hline & & & 1 & 6.7 & & & & \\
\hline & & Total & 15 & 100 & & Total & 5 & 100 \\
\hline
\end{tabular}

Findings related to the views of faculty members regarding the roles of educational leaders in integration of technology into sustainable inclusive education are presented in Table 10 below.

As shown in Table 10, the views of faculty members' on the roles of educational leaders in integration of technology into sustainable inclusive education were analyzed under "competencies and responsibilities" categories. In this context, competencies expected from educational leaders are sustainable inclusive education competencies $(\mathrm{f}=9 ; 29 \%)$, educational leadership competencies $(\mathrm{f}=8$; $25.8 \%)$, knowledge of technology competencies $(f=8 ; 25.8 \%)$, and pedagogic competencies $(f=6 ; 19.4 \%)$. Responsibilities expected from educational leaders are providing opportunities and environment for sustainable inclusive education ( $\mathrm{f}=8 ; 27.6 \%$ ), having the ability to be technological leadership ( $f=8 ; 27.6 \%)$, organizing technology equipment and infrastructure $(f=7 ; 24.1 \%)$, and supporting the development and training of teachers $(f=6 ; 20.7 \%)$.

Table 10. Views of faculty members on the roles of educational leaders in integration of technology into sustainable inclusive education.

\begin{tabular}{|c|c|c|c|c|}
\hline Category & Codes & & $\mathbf{f}$ & $\%$ \\
\hline \multirow{5}{*}{ Competencies } & Sustainable inclusive education competencies & & 9 & 29 \\
\hline & Educational leadership competencies & & 8 & 25.8 \\
\hline & Knowledge of technology competencies & & 8 & 25.8 \\
\hline & Pedagogic competencies & & 6 & 19.4 \\
\hline & & Total & 31 & 100 \\
\hline \multirow{5}{*}{ Responsibilities } & $\begin{array}{l}\text { Providing opportunities and environment for } \\
\text { sustainable inclusive education. }\end{array}$ & & 8 & 27.6 \\
\hline & Having the ability to be technological leadership. & & 8 & 27.6 \\
\hline & Organizing technology equipment and infrastructure. & & 7 & 24.1 \\
\hline & Supporting the development and training of teachers. & & 6 & 20.7 \\
\hline & & Total & 29 & 100 \\
\hline
\end{tabular}




\subsection{Findings on the Second Sub-Problem}

As part of the second sub-problem of the study, views of school administrative staffs having the role of educational leadership were investigated. The findings related to the views of school administrative staff on the role of sustainable inclusive education in the integration of migrant and inclusive students are presented in Table 11 below.

Table 11. Views of school administrative staff on the role of sustainable inclusive education in the integration of migrant and inclusive students.

\begin{tabular}{|c|c|c|c|c|}
\hline Category & Codes & & f & $\%$ \\
\hline \multirow{5}{*}{ Benefit } & $\begin{array}{l}\text { Making positive contributions to the teaching-learning } \\
\text { process (developing connectedness, creating awareness, } \\
\text { generating empathy, developing harmony) }\end{array}$ & & 7 & 50 \\
\hline & Creating equal opportunity & & 3 & 22 \\
\hline & Minimizing social differences & & 3 & 22 \\
\hline & Providing an integrated classroom climate & & 1 & 6 \\
\hline & & Total & 14 & 100 \\
\hline
\end{tabular}

According to the findings in Table 11, school administrative staff expressed that integration of migrant and inclusive students through sustainable inclusive education positively contributed to the teaching-learning process $(\mathrm{f}=7 ; 50 \%)$, created equal opportunities $(\mathrm{f}=3 ; 22 \%)$, minimized social differences $(\mathrm{f}=3 ; 22 \%)$, and provided an integrated classroom climate $(\mathrm{f}=1 ; 6 \%)$.

Findings related to the school administrative staffs' views on conditions that schools should meet in terms of using technology in sustainable inclusive education are given in Table 12 below.

Table 12. Views of school administrative staff on conditions that schools should meet in terms of using technology in sustainable inclusive education.

\begin{tabular}{|c|c|c|c|}
\hline Codes & & f & $\%$ \\
\hline Smart and interactive boards & & 5 & 29.4 \\
\hline Internet and web tools (web 2.0, etc.) & & 4 & 23.5 \\
\hline Audio and visual video-presentations & & 3 & 17.6 \\
\hline Computer and projector & & 2 & 11.8 \\
\hline Technological tools and materials & & 2 & 11.8 \\
\hline \multirow[t]{2}{*}{$\begin{array}{c}\text { Consideration of sustainable inclusive education in technological } \\
\text { physical conditions and infrastructure }\end{array}$} & & 1 & 5.9 \\
\hline & Total & 17 & 100 \\
\hline
\end{tabular}

As seen in Table 12, school administrative staff emphasized that smart and interactive boards $(\mathrm{f}=5 ; 29.4 \%)$, internet and web tools $(\mathrm{f}=4 ; 23.5 \%)$, and audio-visual video-presentations $(\mathrm{f}=3 ; 17.6 \%)$ were the basic tools and conditions that schools should meet in terms of using technology in sustainable inclusive education.

Findings related to the school administrative staffs' views on the suitability of their schools for the use of technology in sustainable inclusive education and the technological equipment and conditions their schools meet are given in Table 13 below. 
Table 13. Views of school administrative staff on suitability of their schools for the use of technology in sustainable inclusive education and the technological equipment and conditions their schools meet.

\begin{tabular}{|c|c|c|c|c|}
\hline Codes & & & $\mathbf{f}$ & $\%$ \\
\hline \multirow{5}{*}{ Adequacies } & Projector & & 4 & 30 \\
\hline & Smart board & & 4 & 30 \\
\hline & Computer & & 3 & 24 \\
\hline & Internet & & 2 & 16 \\
\hline & & Total & 13 & 100 \\
\hline \multirow{5}{*}{ Inadequacies } & Shortage of interactive boards & & 3 & 37.5 \\
\hline & Shortage of technological infrastructure & & 3 & 37.5 \\
\hline & Shortage of internet & & 1 & 12.5 \\
\hline & Shortage of projectors & & 1 & 12.5 \\
\hline & & Total & 8 & 100 \\
\hline
\end{tabular}

As shown in Table 13, school administrative staff considered the number of projectors and smart boards in schools adequate $(\mathrm{f}=4 ; 30 \%)$, but they found the number of interactive boards and technological infrastructure inadequate $(\mathrm{f}=3 ; 37.5 \%)$.

Findings related to the school administrative staffs' views about the positive effects of using technology in sustainable inclusive education are given in Table 14 below.

Table 14. Views of school administrative staff on the positive effects of using technology in sustainable inclusive education.

\begin{tabular}{|c|c|c|c|}
\hline Codes & & f & $\%$ \\
\hline Active and permanent learning & & 3 & 17.6 \\
\hline Direct access to information & & 3 & 17.6 \\
\hline Behavior change in self-understanding and self-disclosure & & 3 & 17.6 \\
\hline Supporting multiple intelligence learning & & 2 & 11.8 \\
\hline Effective use of visual media & & 2 & 11.8 \\
\hline Effective use of time & & 1 & 5.9 \\
\hline Using technology-assisted programs and developing mastery & & 1 & 5.9 \\
\hline Minimizing social differences & & 1 & 5.9 \\
\hline Providing technology-based communication & & 1 & 5.9 \\
\hline & Total & 17 & 100 \\
\hline
\end{tabular}

As seen in Table 14, the school administrative staff stated that using technology in sustainable inclusive education had some positive effects such as allowing students' active and permanent learning $(\mathrm{f}=3 ; 17.6 \%)$, direct access to information $(\mathrm{f}=3 ; 17.6 \%)$, and behavior change in self-understanding and self-disclosure $(\mathrm{f}=3 ; 17.6 \%)$.

The findings related to the school administrative staffs' views on how they support teachers and students for the effective use of technology in sustainable inclusive education as educational leaders are given in Table 15 below.

Table 15. Views of school administrative staff as educational leaders on how they support teachers and students for the effective use of technology in sustainable inclusive education.

\begin{tabular}{|c|c|c|c|}
\hline Codes & & $\mathbf{f}$ & $\%$ \\
\hline Providing technological technical support & & 6 & 37 \\
\hline Directing to the education information network platform & & 3 & 18 \\
\hline Creating project-course and activity & & 3 & 18 \\
\hline Being a role model—guiding & & 2 & 13 \\
\hline Encouragement & & 1 & 7 \\
\hline Providing teaching materials & & 1 & 7 \\
\hline & Total & 16 & 100 \\
\hline
\end{tabular}


According to the findings in Table 15, to enable students and teachers to make effective use of technology in sustainable inclusive education, the school administrative staff claimed that they provided some opportunities such as providing technological technical support $(\mathrm{f}=6 ; 37 \%)$, directing students to the Education Information Network platform, and creating project-course activities $(f=3 ; 18 \%)$.

\subsection{Findings on the Third Sub-Problem}

Within the scope of the third sub-problem of the study, the teachers' perspectives were investigated. Findings related to the teachers' views on sustainable inclusive education practices are presented in Table 16 below.

Table 16. Views of teachers on the use of sustainable inclusive education practices.

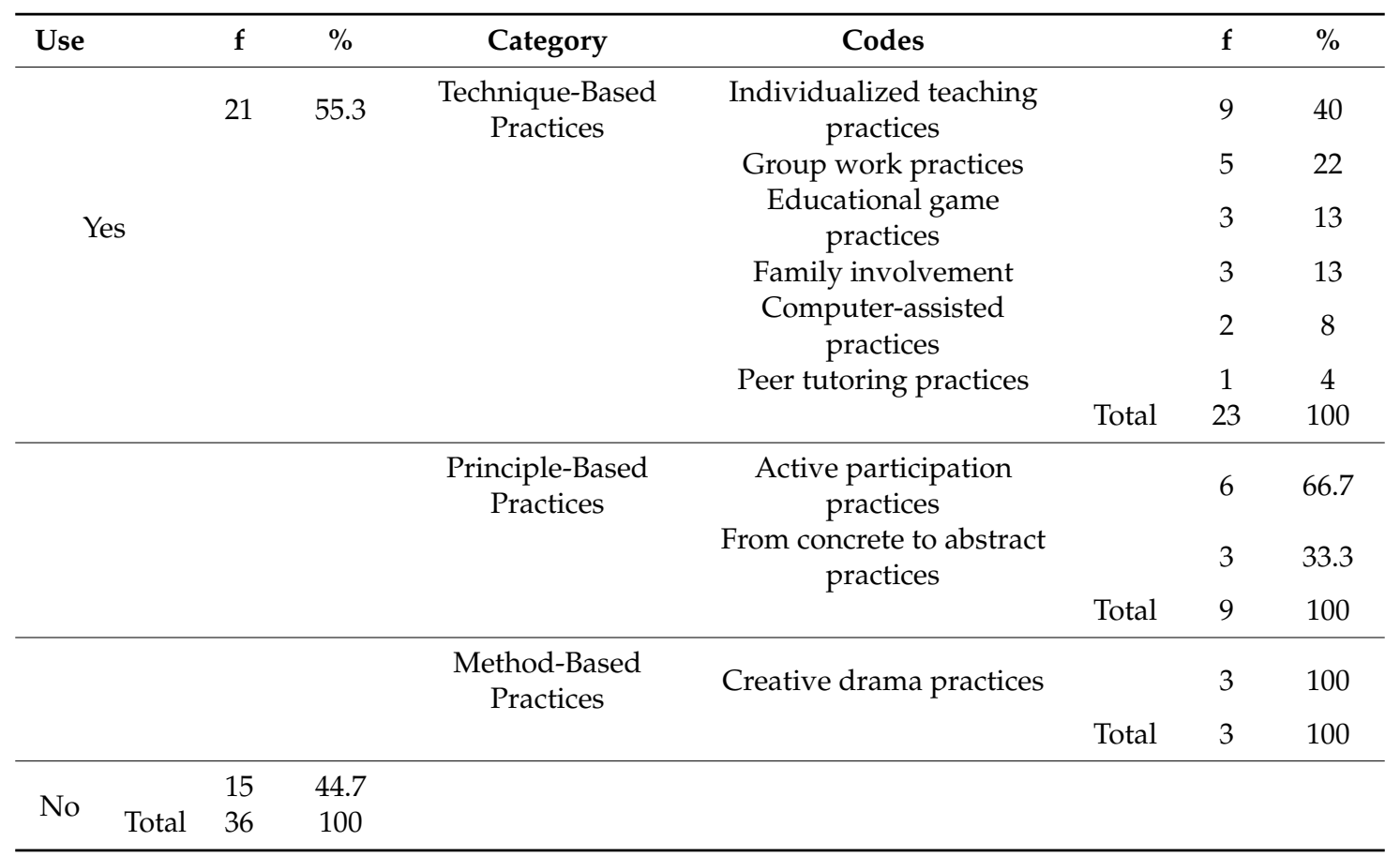

According to Table 16, it was found that teachers mostly included sustainable inclusive education practices in teaching-learning processes $(f=21 ; 55.3 \%)$, but some of teachers did not include these practices $(f=15 ; 44.7 \%)$. Practices used by teachers were analyzed by dividing them into the categories of "technique-based practices, principle-based practices, and method-based practices". Teachers who claimed that they applied sustainable inclusive education practices reported that they mostly used individualized teaching $(\mathrm{f}=9 ; 40 \%)$, group work $(\mathrm{f}=5 ; 22 \%)$, and educational game practices $(\mathrm{f}=3$; $13 \%)$ as technique-based practices. On the other hand, they stated that they applied active participation $(\mathrm{f}=6 ; 66.7 \%)$ in principle-based practices, while applying creative drama practices $(\mathrm{f}=3 ; 100 \%)$ in method-based practices.

The findings related to the teachers' views on principles, methods, techniques, strategies, and educational tools appropriate to use in sustainable inclusive education are given in Table 17 below.

As shown in Table 17, it was found that teachers mostly used the active participation principle $(\mathrm{f}=3 ; 60 \%)$, demonstration-performance method $(\mathrm{f}=3 ; 34 \%)$, and group teaching technique $(\mathrm{f}=13$; $40.6 \%$ in sustainable inclusive education. As educational tools, they preferred audio/visual materials $(\mathrm{f}=7 ; 87.5 \%)$. 
Table 17. Views of teachers on principles, methods, techniques, strategies, and educational tools appropriate to use in sustainable inclusive education.

\begin{tabular}{|c|c|c|c|c|}
\hline Category & Codes & & $\mathbf{f}$ & $\%$ \\
\hline \multirow{3}{*}{ Principles } & Active participation & & 3 & 60 \\
\hline & Functionality & & 2 & 40 \\
\hline & & Total & 5 & 100 \\
\hline \multirow{6}{*}{ Techniques } & Group teaching & & 13 & 40.6 \\
\hline & Computer-assisted teaching & & 8 & 25 \\
\hline & Individualized teaching & & 7 & 21.9 \\
\hline & Educational game-based teaching & & 3 & 9.4 \\
\hline & Out-of-school teaching & & 1 & 3.1 \\
\hline & & Total & 32 & 100 \\
\hline \multirow{7}{*}{ Methods } & Demonstration-performance & & 3 & 34 \\
\hline & Creative drama & & 2 & 22 \\
\hline & Case study investigation & & 1 & 11 \\
\hline & Discussion & & 1 & 11 \\
\hline & Problem-solving & & 1 & 11 \\
\hline & Direct instruction & & 1 & 11 \\
\hline & & Total & 9 & 100 \\
\hline \multirow{3}{*}{ Educational Tools } & Audio/visual materials & & 7 & 87.5 \\
\hline & Educational videos & & 1 & 12.5 \\
\hline & & Total & 8 & 100 \\
\hline
\end{tabular}

The findings related to the views of teachers on the integration of technology into sustainable inclusive education are given in Table 18 below.

Table 18. Views of teachers on integration of technology into the sustainable inclusive education.

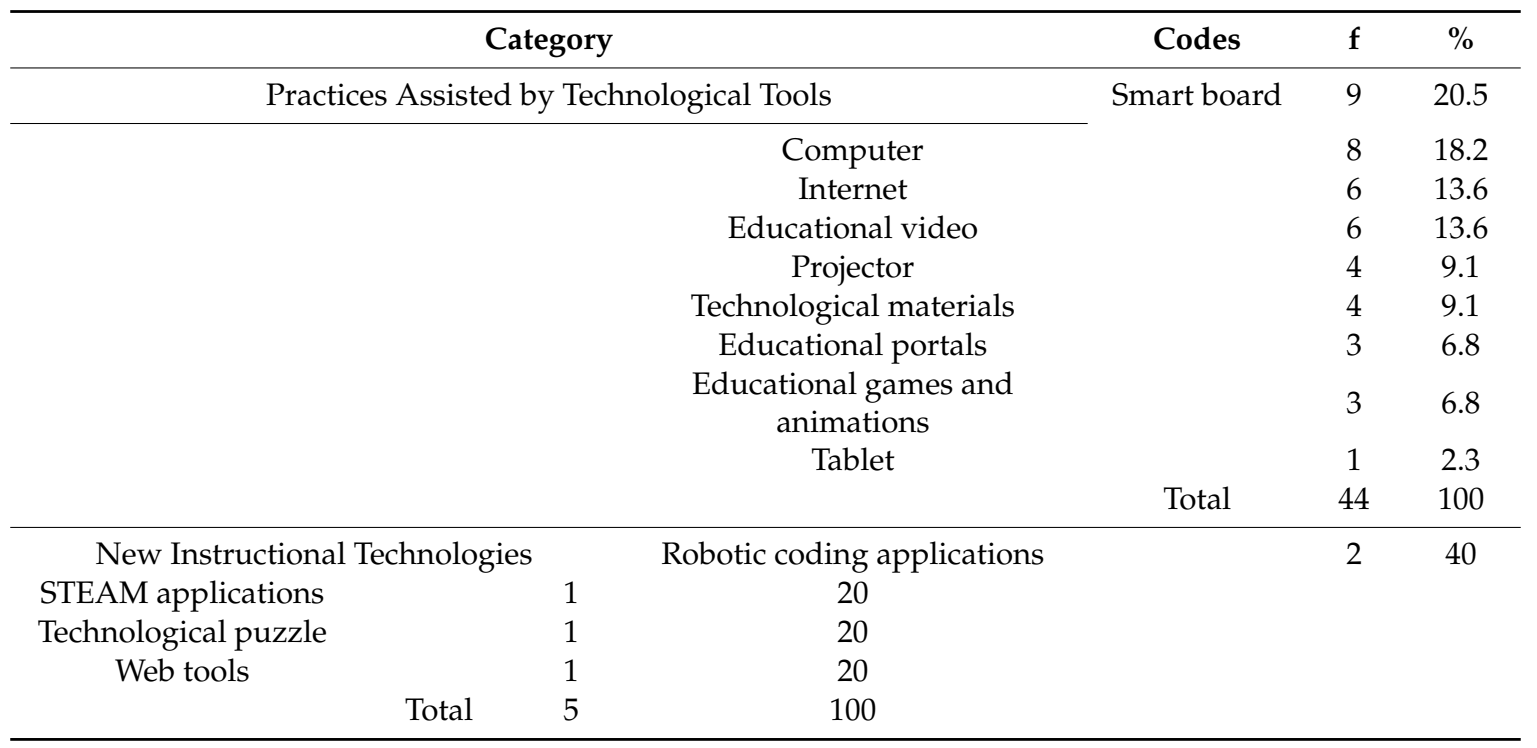

According to Table 18, teachers stated that they mostly used a smart board ( $\mathrm{f}=9 ; 20.5 \%$ ), computer $(\mathrm{f}=8 ; 18.2 \%$ ), internet $(\mathrm{f}=6 ; 13.6 \%)$, and educational videos $(\mathrm{f}=6 ; 13.6 \%$ ) as practices assisted by technological tools in integration of technology into sustainable inclusive education. As new instructional technologies, teachers stated that they used robotic coding applications $(\mathrm{f}=2 ; 40 \%)$, STEAM applications ( $\mathrm{f}=1 ; 20 \%)$, technological puzzles $(\mathrm{f}=1 ; 20 \%)$, and web tools $(\mathrm{f}=1 ; 20 \%)$.

The findings related to the views of teachers on positive and negative effects of integrating technology into sustainable inclusive education are given in Table 19. 
Table 19. Views of teachers on the positive and negative effects of integrating technology into sustainable inclusive education.

\begin{tabular}{|c|c|c|c|c|c|c|c|}
\hline Category & Codes & & $\mathbf{f}$ & $\%$ & Codes & $\mathbf{f}$ & $\%$ \\
\hline \multirow{7}{*}{ Student } & Positive Effect & & & & Negative Effect & & \\
\hline & Permanent learning & & 7 & 26.9 & $\begin{array}{c}\text { Encouraging laziness } \\
\text { (inhibiting research-inquiry } \\
\text { skills) }\end{array}$ & 5 & 50 \\
\hline & Quick and easy learning & & 6 & 23.1 & Causing distraction & 2 & 20 \\
\hline & $\begin{array}{l}\text { Developing technological } \\
\text { skills }\end{array}$ & & 5 & 19.2 & Misusing & 2 & 20 \\
\hline & $\begin{array}{l}\text { Enabling active } \\
\text { participation }\end{array}$ & & 4 & 15.4 & Reducing socialization & 1 & 10 \\
\hline & $\begin{array}{l}\text { Addressing multiple } \\
\text { sensory organs }\end{array}$ & & 4 & 15.4 & & & \\
\hline & & Total & 26 & 100 & & 10 & 100 \\
\hline \multirow{6}{*}{ Teacher } & Positive Effect & & & & Negative Effect & & \\
\hline & $\begin{array}{l}\text { Developing technology } \\
\text { utilization skills }\end{array}$ & & 5 & 45 & Increasing workload & 4 & 45 \\
\hline & $\begin{array}{l}\text { Being able to use different } \\
\text { methods and techniques }\end{array}$ & & 3 & 28 & $\begin{array}{c}\text { Encouraging laziness } \\
\text { (inhibiting research-inquiry } \\
\text { skills) }\end{array}$ & 2 & 22 \\
\hline & Reducing workload & & 2 & 18 & $\begin{array}{l}\text { Reducing teacher-student } \\
\text { interaction process }\end{array}$ & 2 & 22 \\
\hline & $\begin{array}{l}\text { Increasing professional } \\
\text { satisfaction }\end{array}$ & & 1 & 9 & A professional obligation & 1 & 11 \\
\hline & & Total & 11 & 100 & & 9 & 100 \\
\hline
\end{tabular}

According to Table 19, teachers emphasized that integration of technology into sustainable inclusive education had positive effects on students such as enabling permanent learning ( $\mathrm{f}=7$; $26.9 \%)$, enabling quick and easy learning $(f=6 ; 23.1 \%)$, developing technological skills $(f=5 ; 19.2 \%)$, enabling active participation ( $f=4 ; 15.4 \%$ ), and addressing multiple sensory organs $(f=4 ; 15.4 \%$ ). However, teachers highlighted the negative effects of integrating technology in sustainable inclusive education on students such as encouraging laziness $(f=5 ; 50 \%)$, causing distraction $(f=2 ; 20 \%)$, misusing $(\mathrm{f}=2 ; 20 \%)$, and reducing socialization $(\mathrm{f}=1 ; 10 \%)$. They stated that integration of technology into sustainable inclusive education had positive effects on teachers such as developing technology utilization skills ( $f=5 ; 45 \%$ ) and being able to use different methods and techniques $(f=3 ; 28 \%)$ and negative effects such as increasing workload $(\mathrm{f}=4 ; 45 \%)$ and encouraging laziness $(\mathrm{f}=2 ; 22 \%)$.

The findings related to the views of teachers regarding the problems encountered concerning the use of technology in sustainable inclusive education and their solution recommendations are given in Table 20 as follows.

According to Table 20, the problems teachers mentioned are addressed in the categories of "problems caused by technological inadequacies, educational leaders, and physical conditions". Teachers indicated that the major problems in technology utilization in sustainable inclusive education were due to inadequacies of technological equipment $(\mathrm{f}=15 ; 34.1 \%)$, technological infrastructure $(\mathrm{f}=15 ; 34.1 \%)$, insufficient number of educational leaders $(\mathrm{f}=24 ; 61.5 \%)$, and overcrowded classrooms $(\mathrm{f}=5 ; 62.5 \%)$. Under the category "solutions", they proposed improving technological infrastructure $(\mathrm{f}=3 ; 34 \%)$, making classroom sizes manageable $(\mathrm{f}=2 ; 22 \%)$, and increasing technology education quality in sustainable inclusive education $(\mathrm{f}=2 ; 22 \%)$. 
Table 20. Views of teachers on problems encountered concerning the use of technology in sustainable inclusive education and their solution recommendations.

\begin{tabular}{|c|c|c|c|c|}
\hline Category & Codes & & $\mathbf{f}$ & $\%$ \\
\hline \multirow{8}{*}{$\begin{array}{c}\text { Problems Caused by } \\
\text { Technological } \\
\text { Inadequacies }\end{array}$} & & & & \\
\hline & Inadequacy of technological equipment & & 15 & 34.1 \\
\hline & Inadequacy of technological infrastructure & & 15 & 34.1 \\
\hline & Inadequacy of access to out-of-school process & & 4 & 9.1 \\
\hline & Inadequacy of teachers' technology utilization skills & & 4 & 9.1 \\
\hline & Indifference and negative attitudes towards technology & & 3 & 6.8 \\
\hline & Inadequacy of technological software and applications & & 3 & 6.8 \\
\hline & & Total & 44 & 100 \\
\hline \multirow{3}{*}{$\begin{array}{l}\text { Problems Caused by } \\
\text { Educational Leaders }\end{array}$} & Insufficient number of educational leaders & & 24 & 61.5 \\
\hline & Negative attitudes of educational leaders & & 15 & 38.5 \\
\hline & & Total & 39 & 100 \\
\hline \multirow{3}{*}{$\begin{array}{l}\text { Problems Caused by } \\
\text { Physical Conditions }\end{array}$} & Overcrowded classrooms & & 5 & 62.5 \\
\hline & $\begin{array}{c}\text { Inadequacy of physical conditions of school and } \\
\text { classroom }\end{array}$ & & 3 & 37.5 \\
\hline & & Total & 8 & 100 \\
\hline \multirow{6}{*}{ Solutions } & Improving technological infrastructure & & 3 & 33.4 \\
\hline & Making classroom sizes available & & 2 & 22.2 \\
\hline & $\begin{array}{l}\text { Increasing the quality of technology education for } \\
\text { sustainable inclusive education }\end{array}$ & & 2 & 22.2 \\
\hline & Free internet access for teachers and students & & 1 & 11.1 \\
\hline & Opening technology labs at schools & & 1 & 11.1 \\
\hline & & Total & 9 & 100 \\
\hline
\end{tabular}

Findings related to the views of teachers regarding the roles of educational leaders in integration of technology into sustainable inclusive education are presented in Table 21 below.

Table 21. Views of teachers' on the roles of educational leaders in integration of technology into sustainable inclusive education.

\begin{tabular}{|c|c|c|c|c|}
\hline Category & Codes & & f & $\%$ \\
\hline \multirow{6}{*}{ Responsibilities } & Encouraging sustainable inclusive education & & 9 & 23.7 \\
\hline & Creating a technology-friendly school climate & & 9 & 23.7 \\
\hline & Supporting the use of technology & & 8 & 21 \\
\hline & Contributing to teacher development & & 6 & 15.8 \\
\hline & $\begin{array}{l}\text { Providing necessary infrastructure and } \\
\text { arrangements for technology }\end{array}$ & & 6 & 15.8 \\
\hline & & Total & 38 & 100 \\
\hline
\end{tabular}

As shown in Table 21, the views of teachers on the roles of educational leaders in integration of technology into sustainable inclusive education were analyzed under the "responsibilities" category. Encouraging sustainable inclusive education ( $\mathrm{f}=9 ; 23.7 \%)$, creating a technology-friendly school climate $(\mathrm{f}=9 ; 23.7 \%)$, supporting the use of technology $(\mathrm{f}=8 ; 21 \%)$, contributing to teacher development $(\mathrm{f}=6 ; 15.8 \%)$, and providing necessary infrastructure and arrangements for technology $(\mathrm{f}=6 ; 15.8 \%)$ are expressed as responsibilities of educational leaders by teachers.

\section{Discussion}

This study aims to determine the views of teachers, school administrative staff, and faculty members on integration of technology and the role of educational leadership for sustainable inclusive education. Within the sub-problems of the study, it is concluded that faculty members do not consider sustainable inclusive education practices to be at an adequate level in Turkey. They emphasize that 
this is due to the lack of quality in the sustainable inclusive education program. This result suggests that there are deficiencies in the content and implementation processes of the current sustainable inclusive education program in Turkey, and efforts should be made to improve the quality of the content and implementation process of the sustainable inclusive education program. In the study conducted by Sánchez, de Haro-Rodríguez, and Martínez [62], it is obtained that lack of teacher training is considered as one of the biggest barriers for the successful inclusive education. Lpez Torrijo and Mengual-Andrés [63] have pointed out that teacher training is important for the successful inclusion process. Abdelhameed [64] has stated that negative attitudes and lack of awareness on inclusive education across stakeholders and limited teacher and specialist/leader preparation and training are among the most important barriers for sustainable inclusive education. Barnhill, Polloway, and Sumutkaet [65] have stated that teachers are lacking abilities and knowledge for inclusive education.

Faculty members have emphasized that the learning outcomes related to sustainable inclusive education are important in the teacher education program. The findings show that there are deficiencies in the teacher education programs in Turkey in having prospective teachers acquire learning outcomes related to sustainable inclusive education. In this context, it is thought that the inclusive education course content and practices should be integrated into the teacher education program. At this point, it is concluded that integration of sustainable inclusive education courses into teacher education programs and the effective and quality guidance of their content and application process are essential. Teachers occupy an important position in the sustainable inclusion education practices. The effective implementation of sustainable inclusive education is largely depended on the high quality of professional preparation of teachers. Therefore, teachers should be trained about sustainable inclusive principles, and they should take training both at pre-service and in-service stages [66]. Similarly, Jones et al. [67] have emphasized that teachers should be provided with professional development for successful inclusive education. In Ira and Gör's [9] study, it is emphasized that sustainable inclusive education process of faculty members must be guided in a way that enables the provision of the best education to disadvantaged migrant children and that macro education policies must be developed for children in disadvantaged groups in this regard. The result obtained in this study is in parallel to those of Ira and Gör's [9] results.

Faculty members have emphasized the necessity of establishing rich learning environments based on the functionality principle. They have pointed out that student-centered activities such as group work, cooperative learning, individualized teaching, and drama are important and effective activities in sustainable inclusive education for teachers while organizing lessons in sustainable inclusive education. They have also emphasized conducting family involvement activities and creating family guidebooks during the out-of-school periods for the families. These findings may stem from the fact that faculty members consider the in- and out-of-school processes important for the success of sustainable inclusive education and believe that the educational processes must be organized accordingly. Many studies in the literature indicate positive effects of in- and out-of-school activities on students [68-72]. In this study, it is found that teachers' sustainable inclusive education competencies are not at the expected level according to the opinions of faculty members and teachers. Similary, in the study conducted by Starcic [39], it is concluded that teachers' information and communications technology (ICT) competencies and sustainable inclusive education competencies levels are low. According to Starcic [40], it is important for prospective teachers to understand the potentials of educational technology, which helps students with special educational needs and teaching process in inclusive classrooms. In this context, it can be said that learning outcomes regarding sustainable inclusive education competencies related to ICT, which are included and expected to be in the teacher training program for sustainable inclusive education and technology use, are very important for prospective teachers to be successful in future sustainable inclusive education practices.

According to another finding obtained in the study, it is seen that the faculty members have emphasized the importance of using interactive and interactive technology portals effectively for effective use of technology in sustainable inclusive education. In terms of information, media and 
technology skills, "information literacy, media literacy, information, and communications technologies literacy" are important 21st century life skills. In this context, technology-based program needs have arisen in order to facilitate and support educational environments, and interactive technology portal applications have become popular. At this point, it is thought that the integration of interactive and interactive technology applications into the education and training process will provide positive contributions in order to achieve desired outcomes in the sustainable inclusive education process and to support the teaching-learning process.

Faculty members have also emphasized that integration of technology into sustainable inclusive education has a number of advantages such as "reducing workload and encouraging active participation" for teachers. The mobile learning concept, which has entered every field of our lives along with technology, and the principle of learning everywhere at any time are thought to have led to this. It is possible to make the teaching-learning process more flexible and enjoyable through applications such as flipped learning, augmented reality, and second life via mobile learning. This way, the teacher's workload will be reduced as well as the lessons will become more enjoyable during the education process. Faculty members have emphasized that the inadequacy of infrastructure at schools can be a disadvantage for teachers in the process. Technological infrastructure must be perfect and satisfactory to use technology effectively in sustainable inclusive education. This view is thought to be due to the present major deficiencies in schools. Moreover, the emphasis has been made that the integration of technology into sustainable inclusive education can lead to achievements like making the process more enjoyable, increasing retention, and being more motivated. The fact that today's $\mathrm{K}-12$-level students, whom we call the digital generation, are keen on using digital technologies and familiar with computer software and hardware is thought to be the reason behind this. There are many studies in the literature showing the positive effects of digital technologies on students [73-75]. Faculty members evaluated the roles of educational leaders in the integration of technology into sustainable inclusive education in terms of competencies and responsibilities. The competencies expected from educational leaders are defined as inclusive education competencies, educational leadership competencies, knowledge of technology competencies, and pedagogic competencies. It is seen that faculty members almost emphasize these competencies. It is thought that educational leaders who prefer using technology effectively in their school should have sufficient content knowledge of technology, pedagogy, and inclusive education.

School administrative staff have stated that sustainable inclusive education positively contributes to the teaching-learning process in the integration of migrant and inclusive students. Teachers put efforts to create opportunities to have all students make utmost use of the teaching-learning process and develop their potentials through sustainable inclusive education [18-20], and this is the fact that is thought to have led to this. At this point, it could be concluded that sustainable inclusive education contents and practices concerning the teaching-learning processes for students in sustainable inclusive education groups are of great importance and therefore should not be ignored.

The educational and information communication technologies in sustainable inclusive education play a crucial role in creating an effective and adaptable learning environment in teaching-learning processes, especially for students with special educational needs [30,33-38]. In this context, technological infrastructures of schools are expected to be adequate and class sizes convenient. The findings of the study have indicated that overcrowded classrooms and inadequacy of technological infrastructures of schools are the main problems in achieving learning outcomes in the process of integrating technology into sustainable inclusive education. In this context, no matter how good the quality of the sustainable inclusive education program is, sustainable inclusive education cannot achieve its goal unless variables like technological infrastructure of schools and class sizes are feasible. This result of the study supports the findings of the study conducted by Aksoy [76]. Educational leaders state that technology is an important factor for sustainable inclusive education activities in schools, and they are making efforts in this direction. They state that the problems related to the integration of technology for sustainable inclusive education of technology arise from reasons such 
as allowance or physical inadequacy. However, teachers think that educational leaders have a lot of responsibilities in this regard, but some of them are not fulfilled. It is thought that this is due to the fact that educational leaders do not observe teachers, who are practitioners, and do not question their demands and expectations sufficiently. Teachers have emphasized that integration of technology into sustainable inclusive education enables permanent learning, while it can also have a number of negative effects on students such as causing laziness with access to ready-made information, inhibiting research-inquiry skills, and leading to technology addiction. According to Aksoy [76], educational institutions should guide the education process well in order to deal with the types of addictions in individuals and institutions created by new technologies and consider contributing to the utilization and development of technology as a goal.

\section{Conclusions}

In this study, it was aimed to determine the views of teachers, school administrative staff, and faculty members on the integration of technology into sustainable inclusive education and the role of educational leadership. Since there are almost no studies analyzing and interpreting the opinions of teachers, school administrative staff, and faculty members on the integration of technology and the role of educational leaders in sustainable inclusive education through a qualitative research design, this study helps to determine the views of participants who have duties and responsibilities in sustainable inclusive education activities on the use and integration of technology into sustainable inclusive education and the role of educational leaders; and to develop suggestions for the integration of technology into sustainable inclusive education programs accordingly.

The results of the study indicate that faculty members do not consider the sustainable inclusive education practices to be at an adequate level in Turkey. They think that learning outcomes related to sustainable inclusive education are important in the teacher education programs. Additionally, the faculty members have emphasized using rich learning environments, empathy-oriented classroom atmospheres, and flipped classroom models founded on the functionality principle in the category of "organizing classroom climate". On the other hand, school administrative staff have expressed that integration of migrant and inclusive students through sustainable inclusive education positively contributes to the teaching-learning process, creates equal opportunities, minimizes social differences, and provides an integrated classroom climate. It is also determined that teachers mostly include sustainable inclusive education practices in teaching-learning processes, and they mostly use individualized teaching, group work, educational game practices, and family involvement as technique-based practices. Thus, this study proves that different stakeholders that have a key role in providing sustainable inclusive education handle this issue from different perspectives, and they have both positive and negative opinions on the sustainable inclusive education practices.

The purpose of this study was to address a gap in the literature that failed to examine different stakeholders' views on integration of technology and the role of educational leadership for sustainable inclusive education. The findings showed that the practices conducted to ensure sustainable inclusive education were not at the desired level, which indicates that there should be improvements on this issue in Turkey. Therefore, the findings of the study can help policy makers in determining more broad practices in providing sustainable inclusive education. In the literature, it is seen that the studies on inclusive education have been conducted with limited stakeholders. On the contrary, in this study, different stakeholders were included, and therefore more detailed information was attempted to be obtained, which is one of the superior elements of the study.

However, this study has some limitations. Interview technique was conducted to obtain the opinions of the stakeholders. However, especially due to the pandemic process, questionnaire forms were sent to some of the stakeholders via e-mail, and they also sent their replies via e-mail. As a result, face-to-face interviews could not be conducted with all stakeholders included in the study, which is one of the limitations of the study. In addition, this study is limited in terms of time period. 
Another limitation of this study was a small sample size. It would be beneficial to conduct exploratory research with a larger pool of participants.

In the following studies that will be conducted on this issue, a longer time period can be determined, and some observations can be made at schools to understand what practices teachers apply at schools in terms of providing sustainable inclusive education. Similar observations can be conducted at universities. Therefore, it can be better understood whether there are differences between the practices applied by teachers and academic staff in ensuring sustainable inclusive education. This study is designed based on the basic interpretive qualitative study model. In the following studies, the effects of integrating technology into sustainable inclusive education and participants' views can be determined by experimental and mixed-methods designs. More in-depth case studies should be conducted with a larger number of participants. Modern educational programs that integrate technology into curricula and instruction effectively during the sustainable inclusive education process should be developed. Opportunities should be provided for stakeholders in the field of education to create awareness about sustainable inclusive education.

In summary, the study revealed that teachers, school administrative staff, and faculty members have the knowledge of sustainable inclusive education and have emphasized the importance of using technology in sustainable inclusive education. In addition, the fact that teacher competencies in integrating technology into sustainable inclusive education and that technological infrastructures are not at the required level are among the major problems. Therefore, it is concluded that technological equipment of schools should be improved and that learning outcomes related to the use of technology in sustainable inclusive education should be added to the teacher education programs.

Author Contributions: Conceptualization: M.U. and B.A.; data curation: M.U.; formal analysis: H.D. and T.Y.Y.; investigation: M.U. and H.D.; methodology: H.D. and T.Y.Y.; resources: B.A.; supervision: T.Y.Y.; validation: M.U., B.A., and H.D.; writing—original draft: T.Y.Y.; writing—review and editing: B.A. All authors have read and agreed to the published version of the manuscript.

Funding: This research received no external funding.

Conflicts of Interest: The authors declare no conflict of interest.

\section{References}

1. Inclusion International. Better Education for All: When We're Included Too. A Global Report; Instituto Universitario de Integración en la Comunidad: Salamanca, Spain, 2009; Available online: http://ii.gmalik. com/pdfs/Better_Education_for_All_Global_Report_October_2009.pdf (accessed on 3 March 2020).

2. Stubbs, S. Inclusive Education: Where there Are Few Resources; Lewis, I., Ed.; The Atlas Alliance: Oslo, Norway, 2008.

3. Özcan, A.S. Turkey's educational policy for Syrian students in the context of multiculturalism. Int. J. Soc. Studies 2018, 4, 17-29.

4. Taylor, S.C.; Sidhu, R.K. Supporting refugee students in schools: What constitutes inclusive education? Int. J. Incl. Educ. 2012, 16, 39-56. [CrossRef]

5. United Nations Educational, Scientific and Cultural Organization. Policy Guidelines on Inclusion in Education; UNESCO: Paris, France, 2009.

6. Singh, J.D. Inclusive education in India-concept, need and challenges. Sch. Res. J. Hum. Sci. Eng. Lang. (SRJIS) 2016, 3, 3222-3232.

7. Field, S.; Kuczera, M.; Pont, B. No More Failures: Ten Steps to Equity in Education; OECD: Paris, France, 2007; p. 109.

8. Kaysili, A.; Soylu, A.; Sever, M. Exploring major roadblocks on inclusive education of Syrian refugees in school settings. Turk. J. Educ. 2019, 8, 109-128. [CrossRef]

9. İra, N.; Gör, D. Opinions of faculty members of education faculty on inclusive education. Turk. Int. J. Spec. Educ. Guid. Couns. (TIJSEG) 2018, 7, 29-38.

10. United Nations (UN). Transforming Our World: The 2030 Agenda for Sustainable Development. In Proceedings of the 70th Session of the UN General Assembly; Available online: https:// sustainabledevelopment.un.org/post2015/transformingourworld/publication (accessed on 22 March 2020). 
11. Medina-García, M.; Toledo, L.D.; Higueras-Rodríguez, L. Equal opportunities in an inclusive and sustainable education system: An explanatory model. Sustainability 2020, 12, 4626. [CrossRef]

12. Booth, T. The name of the rose: Inclusive values into action in teacher education. Prospects 2011, 41, 303-318. [CrossRef]

13. Purvis, B.; Mao, Y.; Robinson, D. Three pillars of sustainability: In search of conceptual origins. Sustain. Sci. 2019, 14, 681-695. [CrossRef]

14. Scott, R.H. Environmental and social sustainability impacts of teaching and research: Some ideas. eCULTURE 2009, 2, 181-187.

15. Novo-Corti, I.; Pociovalisteanu, D.-M.; Iorgulescu, R.-I. Social sustainability in higher education. The role of institutions from students' point of view. J. Econ. Forecast. 2015, 3, 166-180.

16. Murphy, C.D.R. Educational leaders and inclusive special education: Perceptions, roles, and responsibilities. J. Educ. Cult. Studies 2018, 2, 248. [CrossRef]

17. Banks, A.J. The Routledge International Companion to Multicultural Education; Routledge: New York, NY, USA, 2009; p. 571.

18. Dağlioğlu, H.E.; Doğan, A.T.; Basit, O. What are the teachers doing to identify and develop children's individual skills in inclusive preschool education environment? Gazi Uni. J. Gazi Educ. Fac. (GUJGEF) 2017, 37, 883-910.

19. Sak, U. Gifted Students, 3rd ed.; Vize Publishing: Ankara, Turkey, 2013.

20. Cukierkorn, J.R.; Karnes, F.A.; Manning, S.J.; Houston, H.; Besnoy, K. Serving the preschool gifted child: Programming and resources. Roeper Rev. 2007, 29, 271-276. [CrossRef]

21. Aksoyalp, Y. The qualification of school principal: Instructional leadership. J. Sakarya Educ. Fac. 2010, 20, 140-150.

22. Marulcu, İ. Educational Leadership and Technology Use. Master's Thesis, Süleyman Demirel University, Isparta, Turkey, 2010.

23. Martins, A.A.; Mata, T.M.; Costa, C.A.V. Education for sustainability: Challenges and trends. Clean Technol. Environ. Policy 2006, 8, 31-37. [CrossRef]

24. Goodwin, R.H.; Cunningham, M.L.; Eagle, T. The changing role of the secondary principal in the United States: An historical perspective. J. Educ. Adm. Hist. 2005, 37, 1-17. [CrossRef]

25. Ololube, N.P.; Kpolovie, P.J.; Makewa, L.N. Handbook of Research on Enhancing Teacher Education with Advanced Instructional Technologies. In Reshaping Graduate Education through Innovation and Experiential Learning; Jenkins, T.S., Ed.; IGI Global: Hershey, PA, USA, 2015. [CrossRef]

26. Stegemann, K.C.; Jaciw, A.P. Making it logical: Implementation of inclusive education using a logic model framework. Learn. Disabil. Cont. J. 2018, 16, 3-18.

27. Hoppey, D.; McLeskey, J. A case study of principal leadership in an effective inclusive school. J. Spéc. Educ. 2010, 46, 245-256. [CrossRef]

28. Wagner, J.Y.; Katsiyannis, A. Special education litigation update: Implications for school administrators. NASSP Bull. 2010, 94, 40-52. [CrossRef]

29. Salisbury, C.L. Principals' perspectives on inclusive elementary schools. Res. Prac. Pers. Sev. Disabil. 2006, 31, 70-82. [CrossRef]

30. Wong, A.W.; Chan, C.C.H.; Li-Tsang, C.W.P.; Lam, C.S. Competence of people with intellectual disabilities on using human-computer interface. Res. Dev. Disabil. 2009, 30, 107-123. [CrossRef] [PubMed]

31. Kim, S.; Rosenblith, S.; Chang, Y.; Pollack, S. Will ICMT access and use support URM students' online learning in the (post) COVID-19 era? Sustainability 2020, 12, 8433. [CrossRef]

32. Grönlund, Å.; Lim, N.; Larsson, H. Effective use of assistive technologies for inclusive education in developing countries: Issues and challenges from two case studies. Int. J. Educ. Dev. Using Inf. Commun. Technol. 2010, 6, 5-26.

33. Agboola, I.O.; Lee, A.C. Computer and information technology access for deaf individuals in developed and developing countries. J. Deaf. Stud. Deaf. Educ. 2000, 5, 286-289. [CrossRef] [PubMed]

34. Barak, A.; Sadovsky, Y. Internet use and personal empowerment of hearing-impaired adolescents. Comput. Hum. Behav. 2008, 24, 1802-1815. [CrossRef]

35. Beltrán, E.V.; Abbott, C.; Jones, J. (Eds.) Inclusive Language Education and Digital Technology; Multilingual Matters: London, UK, 2013. 
36. Debevc, M.; Peljhan, Ž. The role of video technology in on-line lectures for the deaf. Disabil. Rehabil. 2004, 26, 1048-1059. [CrossRef] [PubMed]

37. Domagala-Zysk, E. Using technology to teach English as a foreign language to the deaf and hard of hearing. Incl. Lang. Educ. Digit. Technol. 2013, 30, 84-102. [CrossRef]

38. Door, V. Inclusive language education and digital technology. Lang. Learn. J. 2014, 42, 349-350. [CrossRef]

39. Starcic, A.I. Educational technology syllabus. In UP PEF Higher Education 1st Cycle Study Program Classroom Teacher; Course Syllabus, Faculty of Education, University of Primorska: Koper, Slovenia, 2009; pp. 12-15.

40. Starcic, A.I. Educational technology for the inclusive classroom. TOJET Turk. Online J. Educ. Technol. 2010, 9, 26-37.

41. Fakae, B.B. The computer: An indispensable millennium educational tool. Comput. Educ. Res. J. 2014, 1, 1-5.

42. Connor, D.J.; Gabel, S.L.; Gallagher, D.J.; Morton, M. Disability studies and inclusive education-implications for theory, research, and practice. Int. J. Incl. Educ. 2008, 12, 441-457. [CrossRef]

43. Liasidou, A. Inclusive education and critical pedagogy at the intersections of disability, race, gender, and class. J. Crit. Educ. Pol. Studies 2012, 10, 168-184.

44. Peters, S.; Johnstone, C.; Ferguson, P. A disability rights in education model for evaluating inclusive education. Int. J. Incl. Educ. 2005, 9, 139-160. [CrossRef]

45. Zoniou-Sideri, A.; Vlachou, A. Greek teachers' belief systems about disability and inclusive education. Int. J. Incl. Educ. 2006, 10, 379-394. [CrossRef]

46. Dağlioğlu, H.E.; Ömeroğlu, E.; Doğan, A.T.; Şahin, M.G.; Bulut, S.S.; Sabanc1, O.; Kukul, V.; Çakmak, E.K.; Karataş, S. The reliability and validity study of 'classroom practices in inclusive preschool education environment with talented and gifted children scale. Pegem Ĕgitim Öğretim Derg. 2019, 9, 413-434. [CrossRef]

47. Doğrul, H.; Akay, C. Comparison between Syrian and Turkish parents' opinions and expectations about pre-school education. J. Soc. Sci. 2019, 6, 119-139.

48. Razumova, E.; Ruslyakova, E.; Bazhenova, N.; Shpakovskaya, E.; Tokar, O. Engelli çocuklar için yenilikçi psikolojik destek teknolojileri. İlköğretim Online 2019, 18, 539-548. [CrossRef]

49. Mohamed, A.H.H. Attitudes of special education teachers towards using technology in inclusive classrooms: A mixed-methods study. J. Res. Spéc. Educ. Needs 2018, 18, 278-288. [CrossRef]

50. Suleymanov, F. ICDP (International Child Development Programme) in the context of inclusive education. Asian J. Instr. 2015, 3, 61-72.

51. Dow, W. Developing Inclusive communities of learners in technology education: Practical craft skills—facilitator or hindrance. Int. J. Technol. Des. Educ. 2005, 15, 5-17. [CrossRef]

52. Boling, E.C. The transformation of instruction through technology: Promoting inclusive learning communities in teacher education courses. Action Teach. Educ. 2003, 24, 64-73. [CrossRef]

53. Babchuk, W.A. Book review: Qualitative research: A Guide to Design and Implementation (4th ed.), by S. B. Merriam and E. J. Tisdell. Adult Educ. Q. 2016, 67, 71-73. [CrossRef]

54. Magolda, P.M.; Cubberley, M. Qualitative research in practice: Examples for discussion and analysis. J. Coll. Studies Dev. 2003, 44, 566-568. [CrossRef]

55. Tokarczyk, K. Workplace Learning of Professional Academic Advisors at Urban Universities: A Basic Interpretive Qualitative Investigation. Ph.D. Thesis, Cleveland State University, Cleveland, OH, USA, 2012.

56. Lane, J.S. Undergraduate instrumental music education majors' approaches to score study in various musical contexts. J. Res. Mus. Educ. 2006, 54, 215-230. [CrossRef]

57. Palys, T. Purposive sampling. In The Sage Encyclopedia of Qualitative Research Methods; Given, L.M., Ed.; Sage: Los Angeles, CA, USA, 2008; pp. 697-698.

58. Reja, U.; Manfreda, K.L.; Hlebec, V.; Vehovar, V. Open-ended vs. close-ended questions in web questionnaires. Dev. Appl. Stat. 2003, 19, 159-177.

59. Moritsugu, J.; Vera, E.; Wong, F.Y.; Duffy, K.G. Community Psychology, 6th ed.; Routledge: New York, NY, USA, 2019.

60. Yildirim, A.; Şimşek, H. Qualitative Research Methods in Social Sciences, 5th ed.; Seçkin Publishing: Ankara, Turkey, 2006.

61. Miles, M.B.; Huberman, A.M. Qualitative Data Analysis: An Expanded Sourcebook, 2nd ed.; Sage Publications: Thousand Oaks, CA, USA, 1994. 
62. Sánchez, P.A.; De Haro-Rodríguez, R.; Martínez, R.M.M. Barriers to student learning and participation in an inclusive school as perceived by future education professionals. J. New Approaches Educ. Res. 2019, 8, 18-24. [CrossRef]

63. López-Torrijo, M.; Mengual-Andrés, S. An attack on inclusive education in secondary education. Limitations in initial teacher training in Spain. J. New Approaches Educ. Res. 2015, 4, 9-17. [CrossRef]

64. Abdelhameed, $\mathrm{H}$. The development and provision of educational services for children with intellectual disabilities in Egypt. Rev. Bras. Educ. Espec. 2010, 16, 3-18. [CrossRef]

65. Barnhill, G.P.; Polloway, E.A.; Sumutka, B.M. A survey of personnel preparation practices in autism spectrum disorders. Focus Autism Other Dev. Disabil. 2010, 26, 75-86. [CrossRef]

66. Andrew, O.; Danladi, M. Teacher preparation for inclusive education of persons with special needs in Nigeria: The challenges and solutions. Eur. J. Educ. Dev. Psy. 2016, 4, 34-40.

67. Jones, M.N.; Weber, K.P.; McLaughlin, T.F. No teacher left behind: Educating students with ASD and ADHD in the inclusion classroom. J. Spec. Educ. App. 2013, 2, 1-20.

68. Cohen-Vogel, L.; Little, M.; Fierro, C. Evidence-based staffing in high schools: Using student achievement data in teacher hiring, evaluation, and assignment. Lead. Policy Sch. 2017, 18, 1-34. [CrossRef]

69. Duckworth, A.L.; Taxer, J.L.; Eskreis-Winkler, L.; Galla, B.M.; Gross, J.J. Self-control and academic achievement. Annu. Rev. Psychol. 2019, 70, 373-399. [CrossRef] [PubMed]

70. Hahn, Y.; Wang, L.C. The effectiveness of single-sex schools through out-of-school activities: Evidence from South Korea. Oxf. Bull. Econ. Stat. 2018, 81, 369-393. [CrossRef]

71. Steinmann, I.; Strietholt, R.; Caro, D. Participation in extracurricular activities and student achievement: Evidence from German all-day schools. Sch. Eff. Sch. Improv. 2018, 30, 155-176. [CrossRef]

72. Young, J.; Young, J.R.; Ford, D.Y. Culturally relevant STEM out-of-school time: A rationale to support gifted girls of color. Roeper Rev. 2019, 41, 8-19. [CrossRef]

73. Spiteri, M.; Rundgren, S.-N.C. Literature review on the factors affecting primary teachers' use of digital technology. Technol. Knowl. Learn. 2020, 25, 115-128. [CrossRef]

74. Namaziandost, E.; Ziafar, M.; Neisi, L. Students' attitudes toward using flipped classroom model: Focusing on Iranian advanced EFL learners. Eng. Lang. Teach. Res. J. 2020, 1, 16-26.

75. Bond, M.; Buntins, K.; Bedenlier, S.; Zawacki-Richter, O.; Kerres, M. Mapping research in student engagement and educational technology in higher education: A systematic evidence map. Int. J. Educ. Technol. High. Educ. 2020, 17, 1-30. [CrossRef]

76. Aksoy, H.H. An analysis of using technology in educational institutions and its effects. J. Educ. Sci. Soc. 2003, $1,4-23$.

Publisher's Note: MDPI stays neutral with regard to jurisdictional claims in published maps and institutional affiliations.

(C) 2020 by the authors. Licensee MDPI, Basel, Switzerland. This article is an open access article distributed under the terms and conditions of the Creative Commons Attribution (CC BY) license (http://creativecommons.org/licenses/by/4.0/). 